[JAS 1.1 (2003) 7-9]

ISSN 1740-3553

\title{
Editorial: Why a Journal of Anglican Studies?
}

\author{
Bruce Kaye
}

This is the first issue of a new Journal. It is appropriate therefore to outline to the reading public and future subscribers what this Journal is trying to do and why at this particular time it has been launched.

We live in a time of global history when the effects of the spread of colonial empires have become the crux of many of the world's political and social challenges. Anglicanism is a notable form of Christianity which was spread around the globe by a colonizing power and whose inherited public formularies were shaped at a high point of imperial conceptions of politics and social life in England in the sixteenth century. Yet the global Anglican community lacks any sense of a long-standing universal structure or high-level coherence as to its global identity. It stands in some contrast to the universal jurisdictional iconography of Roman Catholicism. The recent spread of Coptic Christianity around the world through emigration has created a similar question about the global identity of that tradition. Anglicanism stands out from these two traditions in that, in the main, it was spread around the globe on the back of a colonizing power in the form of the established church of that power. In a postcolonial environment that very fact creates special and distinctive issues for Anglicans.

From the earliest time the tradition of British Christianity was formed in close engagement with the host society. In the eighth century Bede could write an Ecclesiastical History of the English People which showed a Christianity committedly enmeshed with the particularities of English society and its structures. That principle of enmeshment has been a thread running through the long history of the tradition. In the present circumstances of a global communion set locally in a multitude of different cultures this principle increases the challenge of construing the connecting profile of Anglicanism in its global form.

The formulation of a notion of 'dispersed' authority in Anglicanism at the Lambeth Conference of 1948 was, in the circumstances, both a placarding of the political realities of the day and at the same time an attempt 
to assert a theological principle which went beyond simply baptizing those political realities. It also drew attention to the multi-faceted character of the styles, vehicles and expression of power and authority in Anglicanism.

In the last decades of the twentieth century dispersal has looked more centrifugal than cohering. As a consequence many looked for relations between Anglicans around the world in terms of global jurisdictional organizations legitimated by claims about shared convictions. Such a way of configuring the questions easily led to a public rhetoric peppered with the language of 'orthodox', 'revisionist', 'fundamentalist', 'liberal', even on one very public and shameful occasion 'hardly civilized'. That rhetoric naturally has not led to a greater sense of commonality in the global communion. More fundamentally we have learned that our convictions were often expressed in ways which lacked contextual transferability, let alone sensitivity, and regularly led to miscommunication rather than understanding. Prior and more fundamental work is required.

All of this points to the fact that in the current global circumstances, as Anglicans we need to engage in serious and committed conversation about the distinctives of the Anglican tradition and its experience of such plurality in a shared faith tradition. The Journal of Anglican Studies sets out to provide for and to encourage that conversation among Anglican scholars around the world.

An important aspect of this challenge arises for Anglicans from the enormous disparities between different parts of the world in terms of resources, not just physical resources but, for the purposes of this exercise, resources for scholarship and the development of theological disciplines. It will be important, therefore, for the Journal of Anglican Studies to encourage contributions that reflect the full range of contexts in which Anglican scholars work.

The Journal of Anglican Studies therefore sets out to be:

- a serious conversation across particular contexts;

- a focus on a shared tradition;

- an openness to all aspects of this tradition including history, theology, worship, ethics, Scripture, canon law, aesthetics, education, indeed any aspect that has a place in the tradition of Anglican faith and practice.

In this sense then the Journal of Anglican Studies offers a distinctive contribution to the understanding of Anglicanism and by implication as well our present global environment because of its: 
- focus on Anglicanism as a distinct tradition of Christian faith;

- determinedly global scope and range;

- attention to the multi-faceted challenge of creating a global community.

The Journal of Anglican Studies will therefore welcome contributions from every corner of the globe and from all disciplines, but especially from theology, to contribute to the clarification and renewal of this Anglican tradition of Christian faith. The Journal represents no particular or party point of view and is open to all who wish to contribute to this scholarly endeavour. Information for contributors and about the organizational aspects of the Journal is printed elsewhere in this issue.

The Journal is based in Australia, where it has been brought to birth. It has established institutional links with the church structures in Australia with the Primate as ex officio Patron and the other Metropolitans as Vice Patrons. It has established an Editorial Board with membership drawn from around the world. There are some advantages in being based in Australia for the purposes of sustaining such a conversation. Australia began as a colony and its institutional conservatism has meant that much of the conceptual decolonization going on elsewhere in the world is still required here in Australia.

The style of the cover indicates the character of the Journal; it is modern, open to the future, determinedly global in it concerns and standing under the cross represented by the stars of the Southern Cross as a gesture to the organs of the Journal in Australia. The light coming over the horizon of the earth speaks of the risen glory of the crucified Christ.

The Journal of Anglican Studies has been established in clearly interesting and serious times for Anglicans in order to foster a global scholarly conversation in the service of the renewal of this tradition of Christian faith. 